\title{
Effect of motivation, competence and Islamic leadership on job satisfaction and Teacher performance in vocational high school
}

\author{
Muhammad Abusama ${ }^{1)}$, Murdifin Haming ${ }^{2)}$, Muh. Nasir Hamzah ${ }^{3)}$, Ramlawati ${ }^{4)}$ \\ 1) Doctoral Student in the Faculty of Economics, Muslim University of Indonesia \\ ${ }^{2,3,4)}$ Faculty of Economics, Muslim University of Indonesia \\ Corresponding Author: Muhammad Abusama
}

\begin{abstract}
Based on the type of research is an explanatory research that is used to describe the influence of motivation, competence and Islamic leadership on job satisfaction and teacher performance at 88 teachers Colleges in District South Halmahera in North Maluku province. The results of the analysis of SEM (Structural Equation Modeling) with the help WaphPLS Ver. 5.0 provides evidence that working conditions that support teachers to implement the learning process becomes a lever entire relationship between the variables analyzed. Motivation and competence of teachers made a significant contribution to job satisfaction and performance, significant Islamic leadership on job satisfaction but not significant on teacher performance > job satisfaction proved to contribute significantly to the performance of teachers. On testing indirect effect, there is only one proven as a mediator variable
\end{abstract}

Keywords: Motivation, competence, Islamic leadership, job satisfaction, performance

\section{Introduction}

Management based quality improvement of school is the coordination and harmonization of resources are carried out independently by the school by involving all interest groups associated with the school directly in the decision-making process to meet the needs of school quality or to achieve the quality of schools within the framework of the national education policy (Slamet, Hamid Muhammad, \& Cecep Rustana, 2000: 3). Teachers have a strong role in coordinating, mobilizing, and harmonizing all the educational resources available. A leadership teacher is one of the factors that can encourage schools to be able to realize the vision, mission, goals, and objectives of the school through programs that are implemented in a planned and phased. Therefore, teachers are required to have management and leadership capabilities sufficient to be able to take the initiative / initiatives to improve the quality of education in schools. In addition to these capabilities, the teacher must have the ability or competence is often called teacher competency standards.

The Efforts to prepare the human resources quality future relies heavily on education. The world of education is a vehicle that is gigantic in coaching and human resource development as the capital and the development community. In this context the role of education will increasingly demanded. Government through the Ministry of National Education has implemented an education system in the form of a curriculum that consists of a set of subjects that must be mastered by the educated in the effort to equip and deliver them into the future of human resources that are reliable and good quality. Vocational School (SMK) is a formal education that is one level higher than high school (SMP) that can be enjoyed by the people of Indonesia, where they continue their education to complete compulsory education so that they could become quality human through quality education. The components associated with the school in order to improve the quality of education, including students, teachers, coaches or school administrators, facility / infrastructure and learning process. Empirical facts based on previous research findings show that there are differences in the findings in analyzing the influence of work motivation on job satisfaction, that motivation significantly influence job satisfaction of teachers (Singh \& Sharma, 2016; Ahmed et al., 2010). Results are obtained denials from other researchers, that motivation not significant effect on job satisfaction (Dhermawan et al., 2012). Inconsistency other findings shown in studies that analyze the impact of competence on job satisfaction, the majority of the research findings indicate that competence is significant effect on job satisfaction (Hardjanto, 2017; Danang, 2014). However, the overall results of the study contradicted other researchers that competence not significant effect on job satisfaction (Antonacopoulou \& Fitz, 1996).

Causality among other variables were constructed in this study, the influence of Islamic leadership on job satisfaction, based on previous research findings prove that the leadership have a significant effect on job satisfaction (Hardjanto, 2017). The findings differ from the findings of other researchers that leadership is a negative and significant effect on employee job satisfaction (Brahmasari \& Suprayetno, 2009). Leadership style 
has no significant on employee satisfaction (Bakhri et al., 2015). The previous studies provide evidence that motivation significantly influence performance (Tone et al., 2015; Brahmasari \& Suprayetno 2009) obtains rebuttal evidence from other researchers, that motivation not significant effect on performance (Hardjanto, 2017). Other results showed that the intrinsic factor have a significant on lecturer performance, whereas extrinsic factors is a negative and significant effect on lecturers performance (Rimadias et al., 2017).

One of the factors that affect the high or low performance is a factor of competency, the results of previous studies proving that competence is a positive and significant effect on employee performance (Danang, 2014). The fact is not supported by the findings of other researchers, that competence is not significant influence on the performance of individual (Hardjanto, 2017; Tone et al., 2015). In addition to motivation and competencies, individual performance is also influenced by the Islamic leadership, that the Islamic leadership is a positive and significant effect on individual performance (Tone et al., 2015). The evidence was rejected by other researchers, that leadership is not significant effect on performance (Hardjanto, 2017; Bakhri et al., 2015). Work motivation, competence, the Islamic leadership in the creation of high performance cannot be done directly, as evidenced by the inconsistencies between the findings in analyzing the influence of these variables. That requires also support job satisfaction. Results of previous studies provide evidence that job satisfaction have a significant effect on individual performance (Hardjanto, 2017; Bakhri et al., 2015; Brahmasari \& Suprayetno, 2009). These results differ from the findings that prove that job satisfaction is positive but insignificant on performance (Rimadias et al., 2017).

\section{Work Motivation}

\section{Literature Review}

Motivation refers to an individual's behavior underlies reason to carry anything. (Guay et al., 2010) suggests that the motive is a reason to do something. Therefore Motivation is meaning with the strength and direction of behavior and the factors that predispose a person to behave in a certain way. Robbins (2006) suggested that the motivation is a process that shows the individual intensity, direction, and persistence of effort toward achieving the goal. While the motivation in a general sense with regard to efforts to achieve both individual goals and objectives of the organization.

Motivation is high willingness to make efforts to achieve organizational goals conditioned by the effort's ability to meet the needs of a particular individual. Motivation as a system that consists of (Luthans (2006), (1) requirement, that requirement is created every time there is an imbalance of psychological and physiological, (2) Encouragement is an incentive or motive formed to reduce the need, (3) Incentives , is something that will needs and reduce their encouragement.

\section{Islamic leadership}

Miftah Thoha (2008: 259) argues that leadership is an activity to influence people to be taken to achieve organizational goals. Moeheriono (2013: 415) describes in detail and at length about the Islamic leadership. In the life of the congregation, leaders like the head of his limbs, it has a strategic role in setting pattern (Minhaj) and movement (harakah). Skill in the lead will lead his people to the objectives to be achieved, namely the dignity and welfare of the accompaniment of the blessing of Allah, as Allah says in the Qur'an (QS. Al-Baqarah; 207). "And among people there is someone who sacrificed himself, seeking the pleasure of Allah, and Allah trustees to his servants".

Leadership in Islam as practiced by Muhammad Prophet SAW, where the leadership style according to the Qur'an, as narrated by A'ishah R.A, that ahlaq Rasulullah SAW, it is the Qur'an, which means that every action Muhammad Prophet SAW, is in accordance with the instructions of the Qur'an or in other words that the actions of Muhammad Prophet SAW was a manifestation of the Holy Qur'an. Then how the Al-Qur'an to guide and lead? In the Qur'an Allah says in (As-Sajadah; 24) that which means "And we made them imams (leaders) that gives a clue to our command when they were patient, and are they convinced verses us",

\section{Job Satisfaction}

All people always expect their workers a sense of satisfaction in work or satisfied with their work. In a general sense of job satisfaction is a person's attitude toward what is obtained from the results of his work. If the results obtained in accordance with expectations in accordance with the facts, then someone will give rise to a feeling of satisfaction. Conversely, if the different results obtained or not in accordance with expectations, then the person will not feel satisfied. Job satisfaction as a general attitude of an individual towards his job. While the opinion Kreitner \& Kinicki (2005) suggested that job satisfaction is an emotional response to one's work (Robbins, 2006: 201).

Job satisfaction is a pleasurable or positive emotional state the resulting from the appraisal of one's job or job experience ". This means that job satisfaction is an emotional expression that is positive or pleasant as the result of an assessment of a job or work experience (Luthans, 1998). Job satisfaction is the favorableness with 
employees view Reviews their work (Mangkunagara, 2005). From these opinions can be stated that job satisfaction implies a very important both in terms of the organization and its workers and the general public. It can be interpreted that the employee should be placed on the work according to the abilities and skills background. Therefore, it is proper leadership to create conditions that are positive in the work environment and absolute to do.

As'ad (2004) states that the factors that affect a person's job satisfaction is as follows: (1) Psychological factors; is a psychological factors related to employees, include; interest, tranquility in the work, attitudes toward work, talent and skill, (2) Social factors; the factors related to social relation, both among fellow employees, superiors and employees of different types of work. (3) Physical factors; is a factor associated with physical conditions working environment and the physical condition of the employees, including the type of work, working time arrangements and rest, work equipment, state of the room, the air temperature, lighting, ventilation, employee health condition, age and so on. (4) Financial Factors; is a factor associated with the guarantee as well as the welfare of employees, which includes the system and the amount of salary or wages, social security, all kinds of benefits, facilities provided, promotions and so on.

\section{Performance}

Robbins (2006) suggests that the performance is a function of interaction between the ability or abilities (A), motivation or motivation $(\mathrm{M})$ and the chance or opportunity $(\mathrm{O})$, namely performance $=\mathrm{f}(\mathrm{AxMxO})$, means that performance is a function of ability, motivation, and opportunity. Performance on the individual may also be referred to job performance, work outcomes, task performance (Baron \& Greenberg, 1990: 21), while according to Bernardin \& Russell (2000) provide a definition of the performance of that achievement is a record of the results obtained from the function specific work-function or activity for a certain period.

The performance of a teacher is individual, because every teacher has a different ability levels - different in their job. The management can measure the employees on their performance based on the performance of each - each employee. Performance is an action, not events. Performance action itself consists of many components and is not a result that can be seen at that time as well. Basically, the performance is something that is individualized, because each employee has a different ability levels in their job. Performance depends on a combination of ability, effort, and opportunity gained. This means that the performance was the work of employees in the work for a certain time period and the emphasis is on the work completed within the time period specified employee (Timpe, 1993: 3).

\section{Methods}

Based on the type of research is an explanatory research that is used to describe the effect of motivation, competence and Islamic Leadership on Job Satisfaction and Teacher Performance in Vocational High School in the District of South Halmahera in North Maluku province who number as many as 88 teachers. Hypothesis testing is done using SEM (Structural Equation Modeling) with the WaphPLS Ver. 5.0 as research equipment.

\section{Results}

Table 1. Characteristics of respondents

\begin{tabular}{|c|c|c|c|}
\hline \multicolumn{2}{|c|}{ Characteristics } & $\begin{array}{c}\text { Frequency } \\
(n=88)\end{array}$ & Percent (\%) \\
\hline \multirow{2}{*}{ Gender } & Male & 61 & 69.32 \\
& Female & 27 & 30.68 \\
\hline \multirow{2}{*}{ Age (years) } & $31-40$ & 29 & 32.95 \\
& $41-50$ & 46 & 52.77 \\
& $51 \geq$ & 13 & 25,27 \\
\hline \multirow{2}{*}{ Level of education } & Graduate degree & 49 & 55.68 \\
& Masters programs & 39 & 44.32 \\
\hline \multirow{2}{*}{ Years of work experience } & $\leq 10$ & 17 & 19.32 \\
& $11-20$ & 43 & 48.86 \\
& $\geq 21$ & 28 & 31.82 \\
\hline
\end{tabular}

The table shows that the frequencies of respondents by sex the male dominance with a total of 61 $(69.32 \%)$ while the rest of the women indicated by $27(30.68 \%)$. Most of the respondents had between the ages of 41-50 years with the number of respondents by 46 teachers $(52.77 \%)$, with the majority of the Graduate level education degree program with 49 teachers $(55.68 \%)$, as well as working period $11-20$ years as many as 43 teachers $(48.86 \%)$. 


\section{Goodness of fit model}

The p-value for the average path coefficient (APC) and the ARS and the R-squared value Average (ARS) must be $<0.05$ or significant meaning. Additionally Average full co linearity VIF (AFVIF) as an indicator of multicollinearity should $<5$. For it can be shown in the following table:

Table 2. Goodness of fit model

\begin{tabular}{|l|l|l|}
\hline \multicolumn{1}{|c|}{ Measurement } & \multicolumn{1}{|c|}{ Model 1 } & \multicolumn{1}{|c|}{ Model 2} \\
\hline Average path coefficient (APC) & $0.246, \mathrm{P}=0.004$ & $0.258, \mathrm{P}=0.003$ \\
\hline Average R-squared (ARS) & $0.270, \mathrm{P}=0.002$ & $0.329, \mathrm{P}<0.001$ \\
\hline $\begin{array}{l}\text { Average adjusted R-squared } \\
\text { AARS) }\end{array}$ & $0.244, \mathrm{P}=0.004$ & $0.305, \mathrm{P}<0.001$ \\
\hline Average block VIF (AFVIF) & 1.045, acceptable if $<=5$, ideally $<=3.3$ & 1.045, acceptable if $<=5$, ideally $<=3.3$ \\
\hline $\begin{array}{l}\text { Average full collinearity VIF } \\
\text { (AFVIF) }\end{array}$ & 1.260, acceptable if $<=5$, ideally $<=3.3$ & 1.229, acceptable if $<=5$, ideally $<=3.3$ \\
\hline Tenenhaus GoF (GoF) & $\begin{array}{l}0.387, \text { small }>=0.1, \text { medium }>=0.25, \text { large } \\
>=0.36\end{array}$ & $\begin{array}{l}0.465, \text { small }>=0.1, \text { medium }>=0.25, \text { large } \\
>=0.36\end{array}$ \\
\hline Sympson's paradox ratio (SPR) & 0.833, acceptable if $>=0.7$, ideally $=1$ & 1.000, acceptable if $>=0.7$, ideally $=1$ \\
\hline $\begin{array}{l}\text { R-squared contribution ratio } \\
\text { RSCR) }\end{array}$ & 0.999, acceptable if $>=0.9$, ideally $=1$ & 1.000, acceptable if $>=0.9$, ideally $=1$ \\
\hline Statistical suppression ratio (SSR) & 1.000, acceptable if $>=0.7$ & 1.000, acceptable if $>=0.7$ \\
\hline $\begin{array}{l}\text { Nonlinear bivariate causality } \\
\text { direction ratio (NLBCDR) }\end{array}$ & 0.583, acceptable if $>=0.7$ & 0.667, acceptable if $>=0.7$ \\
\hline
\end{tabular}

The results showed that the test results the suitability of the model (Goodness of fit model) has been met (Kock, 2011).

\section{Validity and reliability construct}

Table 3a. Combined Loading and cross-loadings (Model 1)

\begin{tabular}{|c|c|c|c|c|c|c|c|c|}
\hline Measurement & Worm & Com & Ismld & Jos & Tchr & Type (a & $\mathrm{SE}$ & $\mathrm{P}$ value \\
\hline $\mathrm{X} 11$ & $(0.718)$ & 0.039 & -0.137 & -0.191 & -0.180 & Reflective & 0.087 & $<0.001$ \\
\hline $\mathrm{X} 12$ & $(0.745)$ & 0.086 & 0.132 & -0.068 & 0.003 & Reflective & 0.086 & $<0.001$ \\
\hline $\mathrm{X} 13$ & $(0.358)$ & -0.046 & 0.102 & 0.327 & 0.133 & Reflective & 0.096 & $<0.001$ \\
\hline $\mathrm{X} 14$ & $(0.655)$ & -0.257 & -0.266 & 0.101 & 0.188 & Reflective & 0.088 & $<0.001$ \\
\hline $\mathrm{X} 15$ & $(0.762)$ & -0.073 & 0.008 & 0.260 & 0.109 & Reflective & 0.085 & $<0.001$ \\
\hline $\mathrm{X} 16$ & $(0.782)$ & 0.197 & 0.170 & -0.106 & -0.078 & Reflective & 0.085 & $<0.001$ \\
\hline $\mathrm{X} 17$ & $(0.743)$ & -0.008 & -0.002 & -0.148 & -0.088 & Reflective & 0.086 & $<0.001$ \\
\hline $\mathrm{X} 21$ & 0.057 & $(0.617)$ & 0.214 & 0.038 & 0.253 & Reflective & 0.089 & $<0.001$ \\
\hline $\mathrm{X} 22$ & -0.199 & $(0.648)$ & -0.132 & 0.193 & -0.150 & Reflective & 0.088 & $<0.001$ \\
\hline $\mathrm{X} 23$ & 0.138 & $(0.702)$ & -0.029 & -0.479 & -0.010 & Reflective & 0.087 & $<0.001$ \\
\hline $\mathrm{X} 24$ & -0.007 & $(0.378)$ & -0.070 & 0.495 & -0.137 & Reflective & 0.096 & $<0.001$ \\
\hline $\mathrm{X} 31$ & -0.114 & 0.172 & $(0.837)$ & -0.193 & -0.082 & Reflective & 0.084 & $<0.001$ \\
\hline $\mathrm{X} 32$ & 0.011 & 0.344 & $(0.714)$ & -0.090 & 0.102 & Reflective & 0.087 & $<0.001$ \\
\hline X33 & 0.136 & 0.171 & $(0.547)$ & -0.052 & 0.051 & Reflective & 0.091 & $<0.001$ \\
\hline X34 & -0.134 & 0.174 & $(0.841)$ & -0.211 & -0.091 & Reflective & 0.084 & $<0.001$ \\
\hline $\mathrm{X} 35$ & 0.148 & -0.215 & $(0.787)$ & 0.200 & -0.012 & Reflective & 0.085 & $<0.001$ \\
\hline X36 & -0.021 & -0.245 & $(0.765)$ & 0.111 & -0.055 & Reflective & 0.085 & $<0.001$ \\
\hline X37 & 0.050 & -0.167 & $(0.883)$ & 0.127 & 0.129 & Reflective & 0.083 & $<0.001$ \\
\hline X38 & -0.034 & -0.133 & $(0.830)$ & 0.082 & -0.014 & Reflective & 0.084 & $<0.001$ \\
\hline X39 & 0.123 & -0.200 & $(0.073)$ & 0.125 & -0.088 & Reflective & 0.104 & 0.243 \\
\hline Y11 & 0.058 & -0.078 & -0.031 & $(0.722)$ & 0.105 & Reflective & 0.086 & $<0.001$ \\
\hline Y12 & -0.040 & 0.052 & -0.006 & $(0.807)$ & -0.017 & Reflective & 0.084 & $<0.001$ \\
\hline Y13 & 0.053 & -0.046 & -0.003 & $(0.815)$ & -0.004 & Reflective & 0.084 & $<0.001$ \\
\hline Y14 & -0.068 & 0.067 & 0.038 & $(0.777)$ & -0.077 & Reflective & 0.085 & $<0.001$ \\
\hline Z11 & -0.235 & 0.142 & 0.123 & -0.163 & $(0.840)$ & Reflective & 0.084 & $<0.001$ \\
\hline Z12 & 0.110 & 0.056 & -0.098 & 0.065 & $(0.884)$ & Reflective & 0.083 & $<0.001$ \\
\hline Z13 & 0.048 & 0.053 & -0.006 & 0.259 & $(0.823)$ & Reflective & 0.084 & $<0.001$ \\
\hline Z14 & 0.043 & 0.038 & -0.028 & 0.112 & $(0.918)$ & Reflective & 0.082 & $<0.001$ \\
\hline $\mathrm{Z15}$ & 0.040 & -0.126 & -0.026 & -0.035 & $(0.915)$ & Reflective & 0.082 & $<0.001$ \\
\hline Z16 & -0.004 & -0.095 & 0.015 & -0.043 & $(0.951)$ & Reflective & 0.081 & $<0.001$ \\
\hline Z17 & -0.015 & -0.050 & 0.030 & -0.202 & $(0.809)$ & Reflective & 0.084 & $<0.001$ \\
\hline
\end{tabular}

Measurement outer model or models of construct validity and reliability. This output is used investigators to report the test results of the convergent validity of the measurement instrument (questionnaire). In Table 3a Combined Loading and cross-loadings still a construct validity convergent $<0.70$ (although p-value $<0.05$ ) and should be removed from the model, as shown in Table $3 \mathrm{~b}$. 
Table 3b. Combined Loading and cross-loadings (Model 2)

\begin{tabular}{|c|c|c|c|c|c|c|c|c|}
\hline Measurement & Worm & Com & Ismld & Jos & Tchr & Type (a & SE & $\mathrm{P}$ value \\
\hline $\mathrm{X} 11$ & $(0.743)$ & 0.023 & -0.147 & -0.150 & -0.162 & Reflective & 0.086 & $<0.001$ \\
\hline $\mathrm{X} 12$ & $(0.748)$ & 0.073 & 0.140 & -0.006 & 0.014 & Reflective & 0.086 & $<0.001$ \\
\hline $\mathrm{X} 14$ & $(0.668)$ & -0.164 & -0.228 & 0.064 & 0.196 & Reflective & 0.088 & $<0.001$ \\
\hline $\mathrm{X} 15$ & $(0.755)$ & -0.009 & 0.028 & 0.261 & 0.099 & Reflective & 0.086 & $<0.001$ \\
\hline $\mathrm{X} 16$ & $(0.777)$ & 0.126 & 0.174 & -0.021 & -0.062 & Reflective & 0.085 & $<0.001$ \\
\hline $\mathrm{X} 17$ & $(0.740)$ & -0.071 & 0.001 & -0.145 & -0.064 & Reflective & 0.086 & $<0.001$ \\
\hline $\mathrm{X} 21$ & -0.065 & $(0.831)$ & 0.131 & 0.209 & 0.098 & Reflective & 0.084 & $<0.001$ \\
\hline $\mathrm{X} 23$ & 0.065 & $(0.831)$ & -0.131 & -0.209 & -0.098 & Reflective & 0.084 & $<0.001$ \\
\hline X31 & -0.089 & 0.116 & $(0.849)$ & -0.146 & -0.069 & Reflective & 0.083 & $<0.001$ \\
\hline $\mathrm{X} 32$ & -0.029 & 0.386 & $(0.669)$ & -0.011 & 0.029 & Reflective & 0.088 & $<0.001$ \\
\hline X34 & -0.126 & 0.158 & $(0.851)$ & -0.163 & -0.096 & Reflective & 0.083 & $<0.001$ \\
\hline $\mathrm{X} 35$ & 0.193 & -0.190 & $(0.778)$ & 0.149 & 0.019 & Reflective & 0.085 & $<0.001$ \\
\hline X36 & 0.013 & -0.207 & $(0.786)$ & 0.050 & -0.025 & Reflective & 0.085 & $<0.001$ \\
\hline X37 & 0.074 & -0.129 & $(0.895)$ & 0.088 & 0.149 & Reflective & 0.082 & $<0.001$ \\
\hline X38 & -0.030 & -0.077 & $(0.848)$ & 0.042 & -0.010 & Reflective & 0.083 & $<0.001$ \\
\hline Y11 & 0.044 & 0.003 & -0.029 & $(0.722)$ & 0.078 & Reflective & 0.086 & $<0.001$ \\
\hline Y12 & -0.065 & 0.055 & -0.009 & $(0.807)$ & -0.035 & Reflective & 0.084 & $<0.001$ \\
\hline Y13 & 0.086 & -0.090 & 0.002 & $(0.815)$ & 0.031 & Reflective & 0.084 & $<0.001$ \\
\hline $\mathrm{Y} 14$ & -0.063 & 0.035 & 0.034 & $(0.777)$ & -0.068 & Reflective & 0.085 & $<0.001$ \\
\hline Z11 & -0.245 & 0.164 & 0.096 & -0.127 & $(0.840)$ & Reflective & 0.084 & $<0.001$ \\
\hline $\mathrm{Z} 12$ & 0.109 & 0.029 & -0.097 & 0.084 & $(0.884)$ & Reflective & 0.083 & $<0.001$ \\
\hline Z13 & 0.062 & -0.014 & -0.014 & 0.272 & $(0.823)$ & Reflective & 0.084 & $<0.001$ \\
\hline Z14 & 0.033 & 0.051 & -0.030 & 0.124 & $(0.918)$ & Reflective & 0.082 & $<0.001$ \\
\hline $\mathrm{Z} 15$ & 0.035 & -0.080 & -0.006 & -0.068 & $(0.915)$ & Reflective & 0.082 & $<0.001$ \\
\hline Z16 & 0.004 & -0.099 & 0.025 & -0.071 & $(0.951)$ & Reflective & 0.081 & $<0.001$ \\
\hline Z17 & -0.010 & -0.038 & 0.031 & -0.217 & $(0.809)$ & Reflective & 0.084 & $<0.001$ \\
\hline
\end{tabular}

The results in table $3 b$ shows that the convergent validity criteria unmet model 1 and model 2 is fulfilled having already qualified, convergent validity of $>0.60$ and significant ( $p$-value $<005$ ) so that model 2 is used for analysis. (Hair et al.,2013).

\section{Composite reliability}

A variable that is deemed capable of (reliable) in explaining the data on these variables, the test can be seen on value the composite reliability and Cronbach's Alpha>0.60, for it could be shown in the following table:

Table 4. Latent variable coefficients (composite reliability) (model 2)

\begin{tabular}{|l|c|c|c|c|c|}
\hline \multicolumn{1}{|c|}{ Measurement } & Worm & Com & Ismld & Jos & Tchr \\
\hline R-Squared & & & & 0.380 & 0.279 \\
\hline Adj. R-Squared & & & & 0.358 & 0.253 \\
\hline Composite reliab. & 0.878 & 0.817 & 0.932 & 0.862 & 0.959 \\
\hline Cronbach's Alpha & 0.833 & 0.852 & 0.913 & 0.786 & 0.950 \\
\hline Avg. Var. Extrac. & 0.546 & 0.690 & 0.662 & 0.610 & 0.772 \\
\hline Full Collin. VIF & 1.230 & 1.115 & 1.088 & 1.248 & 1.464 \\
\hline Q-Squared & & & & 0.401 & 0.281 \\
\hline
\end{tabular}

The value composite reliability for work motivation of $0.878>0.60$ while for the variable Competency of $0.817>0.60$ and the Islamic Leadership amounted to $0.932>0.60$, Teacher satisfaction amounted to 0,862 . Then the teacher's performance at 0,959> 0.60. Furthermore, to Cronbach's Alpha at variable work motivation for $0,833>0.60$. Then for competency variable of $0.852>0.60$. Next on Islamic Leadership for 0.913>0.60. Teachers satisfaction of $0.786>0.60$ latter teachers performance of $0.950>0.60$. On the other measurements that at a value Avg. Var. Extrac. Overall variable has a value of $>0.5$

\section{Discriminant validity}

Test of discriminant validity is evidenced by the results of latent variable output correlations. This output reports the correlation coefficient between the latent variables. The criteria used are the square roots (square roots) average variance extracted (AVE) is a column diagonal bracketed must be higher than the correlation between latent variables in the same column (above or below) (Sholihin \& Dwi, 2013).

Table 4. Correlations among 1.vs. with sq. rts. of Aves (Model 2)

\begin{tabular}{|c|l|l|l|l|l|}
\hline Variables & \multicolumn{1}{|c|}{ Worm } & \multicolumn{1}{|c|}{ Com } & \multicolumn{1}{|c|}{ Ismld } & \multicolumn{1}{c|}{ Tos } & -0.339 \\
\hline Worm & $(0.739)$ & 0.094 & 0.184 & 0.007 & 0.225 \\
\hline Com & 0.094 & $(0.831)$ & -0.051 & 0.018 & -0.059 \\
\hline Ismld & 0.184 & -0.051 & $(0.814)$ & -0.197 & -0.362 \\
\hline Jos & 0.007 & 0.018 & -0.197 & $(0.781)$ & $(0.879)$ \\
\hline Tchr & -0.339 & 0.225 & -0.059 & -0.362 & \\
\hline
\end{tabular}


The table shows that the discriminant validity has been met, which can be seen from the root of AVE on the diagonal column is greater than the correlation between constructs in the same column. The results of this cross-loading an indication of fulfillment of the criteria for the validity diskriminant.

\section{Model and Hypothesis Testing}

The results of testing models and hypotheses suggest that, among the 7 (seven) causality between variables (direct influence) are built in this model, there is one of them which is not significant, that is the influence of Islamic leadership on the performance of which p-value $=0.468>0.05$

Table 5. The path coefficients and P-value (Model 2)

\begin{tabular}{|c|c|c|c|c|c|c|c|c|c|c|}
\hline \multicolumn{9}{|c|}{ Path coefficients } & \multicolumn{7}{c|}{ P-values } \\
\hline Variables & Worm & Com & Ismld & Jos & Tchr & Worm & Com & Ismld & Jos & Tchr \\
\hline Worm & & & & & & & & & & \\
\hline Com & & & & & & & & & & \\
\hline Ismld & & & & & & & & & & \\
\hline Jos & 0.173 & 0.516 & -0.195 & & & 0.046 & $<0.001$ & 0.028 & & \\
\hline Tchr & -0.302 & 0.193 & 0.008 & -0.315 & & 0.001 & 0.029 & 0.468 & $<0.001$ & \\
\hline
\end{tabular}

Figure 1. Hypothesis testing

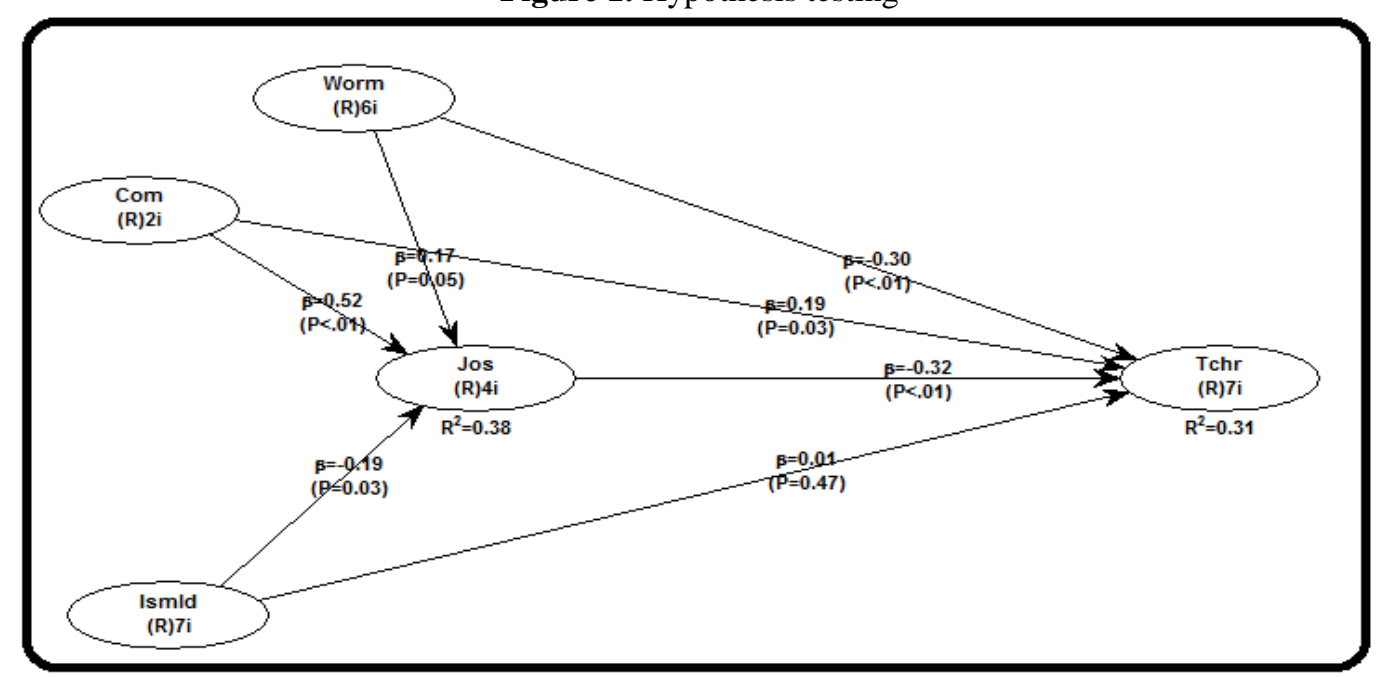

$\mathrm{H}_{1} \quad$ Motivation and job satisfaction of teachers

Motivation is a psychological process that generates and directs the behavior of goal-directed behavior or gold (Wibowo, 2010: 378). Descriptive analysis Showed that teachers in carrying out his work has a high desire to get the award for his work and compliment the results of that work, but in practice the teachers have not received enough support from the government and the management of the school to establish a harmonious relationship among teachers. The effect of work motivation on job satisfaction can be proven with the value path coefficient of 0,173 with positive direction and the $\mathrm{p}$-value $0,046<0,05$. The test results of prove that the first hypothesis, motivation positive and significant impact on job satisfaction Vocational High School teacher in South Halmahera District. This is because teachers gain sufficient support in establishing a harmonious relationship among teachers. The process of drafting the curriculum and Learning Implementation Plan (RPP), the is one teacher workload can be optimally implemented a. Working conditions that support teachers to implement the learning process well be the cause of a positive and significant effect of work motivation on job satisfaction of teachers.

\section{$\mathrm{H}_{2} \quad$ Competence and teacher job satisfaction}

Is the basic characteristics of a person's competence (the individual) that Affect the way of thinking and acting, to generalize to all situations faced and survived long enough in humans (Ruky, 2006). Descriptive analysis showed that teachers have sufficient ability in managing the education of students and to communicate and interaction effectively with the school environment and outside the school environment. Effect of competence on job satisfaction can be demonstrated by the path coefficient value of 0.516 with positive direction and the p-value of $0.001>0.05$. The test results of prove that the second hypothesis, competence and significant positive effect on job satisfaction Vocational High School teacher in South Halmahera District. The 
statement can be interpreted that the teacher has a high ability to communicate and interaction effectively with the environment of the school and outside the school environment which leads to the establishment of social interactions both among teachers, with the leaders, and fellow teacher

Teacher in carrying out their duties always act objectively and non-discriminatory, teachers show empathy in communicating to fellow educators, parents and the community and teachers have a good attitude making it Easier for them to adapt to the environment of diverse cultural and social backgrounds are different as well as the teacher continues to build communication with other professions and other professions both oral and written so that contributes to the high sense of satisfaction that is felt teachers today by fostering a harmonious relationship with the boss and good relationships with colleagues throughout the profession as well as the positive response from employers to achievements obtained d during this teacher to Become a decisive factor in the creation of job satisfaction of teachers' work.

\section{$\mathrm{H}_{3} \quad$ Islamic Leadership and job satisfaction}

In the Islamic perspective, leadership is described as a trust or mandate that involves the psychological contract between leaders and followers to do good deeds. Thus, a leader must have a strong moral character (Ahmad, 2009). Descriptive analysis showed that that the leadership has the ability to behave maintaining himself from the torment of Allah SWT is done by following all the commandments and avoid all of His prohibitions.

The influence of Islamic leadership on job satisfaction can be proven with the value path coefficient of $-0,195$ with negative direction and is evidenced by the p-value $0.028>0.05$. Reviews These results explain that the third hypothesis that Islamic leadership have a significant effect on job satisfaction Vocational High School teacher in South Halmahera District proved to be accepted and supported by empirical facts. Islamic Leadership is good and indicated resources by the principal is not currently shown to provide significant effect (significant) to increase of job satisfaction of teachers. This is Because in carrying out any work, the principal has the ability to always on the straight and always use the same size in the act are Tirrenus with equal treatment for teachers and the community around the school and the make an assessment of the achievements of teachers with fair without looking at the background of the teacher, in its implementation proved to Increase the interest of teachers, tranquility work, attitude towards work and the welfare of teachers, the which later Became the cause positive but not significant influence of Islamic leadership on job satisfaction of teachers.

\section{$\mathrm{H}_{4} \quad$ Motivation and teacher performance}

Work motivation As Becomes an area of interest for the researcher regarding its contribution to the company, it has been defined as a driver for the organization's performance (Dwivedula et al., 2015). For instance, an individual is highly motivated to complete the task and accept the challenging job, he or she will take the initiative to accomplish the work, and his or her performance at work will contribute to a better organizational performance. Thus, having employees with work motivation will contribute to the Organizations' success. Generation Y, Also known as the Millennials (Twenge \& Campbell, 2012)..

Descriptive analysis showed that teachers have the honesty of high moral commitment and willingness of teachers to do the right thing in the right way. The influence of work motivation on teacher performance can be demonstrated by the path coefficient value of -0302 with a negative direction. Influence coefficient is negative, meaning that the low motivation of teachers work, the resulting in a decline in the performance of Vocational High School teacher in South Halmahera District, but it can be evidenced Also by the p-value is $0,001<0.05$ The test results prove that the fourth hypothesis, motivation and significant negative effect on the performance of teachers Vocational High School in South Halmahera District.

The high desire of teachers to obtain awards for his work so far and praise for the work that is inversely proportional to the low level of ability of teachers to the mastery of instructional materials and is represented on the ability of teachers of the method or process of preparing program of learning activities to develop syllabi and lesson plan (RPP) which later became the cause of a negative and significant effect on the performance of teachers' work motivation. Basically Teachers have a strong desire to excel to the fullest, the achievements of teachers during this time due to the professionalism of teachers and achievement for teachers to get appreciation and schools to provide rewards the achievements obtained, these conditions have a significant impact on the willingness of teachers to improve the quality of implementation of learning in order to educate students.

\section{$\mathrm{H}_{5} \quad$ Competence and teachers' performance}

Competency as one of the main components of human capital has been widely accepted as so over the last decade and has been researched in various literatures on human capital (Baron, 2011). Namasivayam \& Denizci (2006) state that there are several elements of human capital at the organizational level such as competence and relationships where competence includes the social (capability to work together in the organization) commercial (capability to work with ex-finn, assets and customers) and the professional 
(capability to utilize organizational structural capital) competence of people. Relationships like social competence, on the other hand, are related to the skill of an individual to create value in collaboration with others in the organization.

Descriptive analysis showed that the teacher has a good ability to manage the learning of students. Influence of competence on teacher performance can be demonstrated by the path coefficient value of 0193 with a positive direction. Influence coefficient is positive, meaning that the competence of teachers is high, resulting in an increase in the performance of teachers such conditions can be evidenced also by the p-value $=0.029$ $<0.05$. The fifth hypothesis testing results prove that, the competence is positive but not significant effect on the performance of teachers Vocational High School in South Halmahera District.

Teachers have sufficient ability to communicate and interact effectively with the environment of the school and outside the school environment so as to improve the ability of teachers to conduct an evaluation of what has been achieved and done in a sustainable manner, but the effect is not obvious, the condition is the cause of a positive and significant influence competence on teacher performance. Teachers do the job always act in an objective and non-discriminatory and continually communicate empathetically to fellow educators, parents and the community and able to adapt to diverse environments and cultures of different social background.

\section{$\mathbf{H}_{6} \quad$ Islamic Leadership and teacher performance}

In the Islamic religion, as revealed through Islam's primary sources, the Qur'an and the Sunnah, is foundational for Islamic leadership. For the faithful, the Koran is the unalterable word of God. The Sunnah describes the life of Prophet Muhammad and is the second source of Islamic jurisprudence after the Koran. The creed of Islam is based on the metaphysical concept of divine unity, or tawhid. The concept of tawhid means that there is only one God, which God is the only Lord of Creation, and that God is morally perfect. Tauhid is also foundational to Islamic ontology and the epistemology that underlies the Islamic worldview. For Islamic leaders, material and spiritual pursuits are Inseparable, and every action is a religious act (Mahmood 2006 Mahmood, A. (2006).

Islam encourages leaders to express Reviews their faith through active participation in all aspects of life, including work (Ali, 1998). The Qur'an Clearly states that "God hath permitted trade" (Qur'an 2: 275), and therefore leaders should strive to Reviews their utmost to be successful and ethical at the same time. As such, Islam prescribes a code of rules for Islamic public administration and business activities. These are all pursuant to the concept of lawful and unlawful, and reflect features of social responsibility in every aspect of the transactions (Halstead, 2007). This being so, business activities that improve the Contribute to the economy and community can become a type of worship if they are performed in line with the Islamic code of conduct.

The results of the descriptive analysis shows that in carrying out his duties leadership must maintaining himself from the torment of Allah SWT is done by following all the commandments and avoid all of His prohibitions. The influence of Islamic leadership on teacher performance can be demonstrated by the path coefficient value of 0.008 with a positive direction. Influence coefficient is positive, meaning that the Islamic leadership is good and indicated by the principal at this time, resulting in an increase in the performance of teachers, but it can be evidenced also by $p$-value $=0.468>0.05$ The test results prove that the sixth hypothesis, Islamic leadership positive and no significant effect on the teachers performance in Vocational High School in South Halmahera District. This is because the principal as the direct supervisor of teachers have the ability to always be on the straight path and the actions and policies pursued by constantly using the same size in the face of the problems faced by teachers that have a significant impact on the ability of teachers to conduct an evaluation on what been achieved which is sustainable

\section{$\mathrm{H}_{7} \quad$ Job satisfaction and Teachers' performance}

There is a clear consensus in the definition of job satisfaction. Their "consensus" definition is that job satisfaction is "an affective (that is, emotional) reaction to one's job, the resulting from the incumbent's comparison of actual outcomes with Reviews those that are desired. This definition is essentially equivalent to the definition offered by Locke in his two classic and influential papers on job satisfaction (Cranny, Smith, \& Stone, 1992). the results of descriptive analysis shows that teachers feel satisfied with the type of work, working time arrangements, work equipment, air circulation, as well as health insurance provided to teachers.

The influence of job satisfaction on teacher performance can be demonstrated by the path coefficient value of estimate at -0315 with a negative direction. The coefficient of influence is negative, meaning that the teacher job satisfaction is low, resulting in a decline in the performance of teachers. Then it can be proven also by $\mathrm{p}$-value $0,001<0,05$. The test results prove that the seventh hypothesis, job satisfaction a significant negative effect on the performance of teachers Vocational High School in South Halmahera District. In practice, the low interest of teachers in a career, tranquility work, attitude towards work and the payroll system is not adequate, social security, benefits, facilities perceived less than optimal but real impact on the creation of a teacher's ability to mastery of instructional materials and honesty teacher, a moral commitment and the desire of teachers 
to do the right thing in the right way into the cause of a negative and significant effect on the performance of teachers' job satisfaction. That the low level of conformity teachers have interest and talent contained within them, a feeling of discomfort in the work, and lack of satisfaction within themselves the educators, proven to provide a significant impact on the high commitment of teachers in improving the quality of learning implementation.

\section{$\mathrm{H}_{8} \quad$ Work motivation and teachers performance : The mediating role of job satisfaction}

The work performance in quality and quantity of work achieved by an employee in performing their duties in accordance with the responsibilities given to him. The level of worker performance is closely related to reward systems implemented by institutions / organizations for which they work. The award handling can affect the improvement of one's performance (Mangkunagara, 2001: 67)

Table 6 Sobel test $\left(\mathbf{H}_{\mathbf{8}}\right)$

\begin{tabular}{|c|c|c|c|c|}
\hline Input: & & Test statistic: & Std. Error: & $p$-value: \\
\hline a 0.173 & Sobel test: & -1.51503869 & 0.03596938 & 0.12976261 \\
\hline$b-0.315$ & Aroian test: & -1.4617868 & 0.03727972 & 0.14379964 \\
\hline$s_{a} 0.101$ & Goodman test: & -1.57456933 & 0.03460946 & 0.11535589 \\
\hline$s_{\mathrm{b}} 0.097$ & Reset all & & Calculate & \\
\hline
\end{tabular}

Referring to hypothesis testing and Sobel test results using the approach of Baron \& Kenny (1986) Computing Sobel Test of Mediation for Baron \& KennyApproach,it can be shown that the value of the path coefficient influence employee motivation through job satisfaction on performance teacher, found the value of Sobel test of -1.515 and p-value of $0.129>0.05$ so that based on these results can be explained that motivation through job satisfaction on performance teacher negative effect but not significant. Low desire of teachers to further pursue personal achievement of the material benefits are realized with passion educating always better than the results previously achieved, but inversely with lower job satisfaction felt by a teacher who is shown with a lower inability of teachers in working time arrangements and the lack of teachers work equipment facilities and low ability of teachers to be honest and having strong character in attitude and action, but it resulted in a decrease in the ability of teachers to provide a description of the knowledge, skills and attitudes to students

\section{$\mathrm{H}_{9} \quad$ Competence and teachers performance: The mediating role of job satisfaction}

Competence (the individual) is the basic characteristics of a person's that affect the way of thinking and acting, to generalize to all situations faced and survived long enough in humans (Ruky, 2006). Competence in relation to the performance can be classified in two groups (Ruky 2006) competency threshold (threshold competencies) that the minimum criteria that must be met office holders in order to work effectively and competence differentiating (differentiating competencies) that the criteria that distinguish people who reach superior performance and those whose performance was average.

Table 7 Sobel test $\left(\mathbf{H}_{\mathbf{9}}\right)$

\begin{tabular}{|c|c|c|c|c|}
\hline Input: & & Test statistic: & Std. Error: & $p$-value: \\
\hline a 0.516 & Sobel test: & -2.81034344 & 0.05783635 & 0.00494887 \\
\hline$b-0.315$ & Aroian test: & -2.77747527 & 0.05852077 & 0.0054783 \\
\hline$s_{a} 0.092$ & Goodman test: & -2.84440679 & 0.05714373 & 0.00444942 \\
\hline$s_{\mathrm{b}} 0.097$ & Reset all & & Calculate & \\
\hline
\end{tabular}

The Sobel test results Computing test of Mediation for Baron \& Kenny Approach, it can be shown that the value of the path coefficient effect of competence through job satisfaction on performance teacher, found the value of Sobel test of -2.810 and p-value of $0.004<0.05$ so that based on these results can be explained that motivation through job satisfaction on performance teacher significant negative effect but not significant.

Factors causing negative and significant effect of competence through job satisfaction on performance teachers due to teacher in carrying out its work always act in an objective and non-discriminatory and 
continually communicate empathetically to fellow educators, parents and the community and able to adapt to the environment of diverse cultural and social background is different, then the teacher has the ability to establish good communication significant impact on the high commitment of teachers in improving the quality of implementation of learning and ability of teachers to always strive to convey to students the teaching materials in accordance with the specified time target to trigger a negative and significant effect of competence through job satisfaction on the performance of teachers.

\section{$\mathrm{H}_{10} \quad$ Islamic leadership and teacher's performance: The mediating role of job satisfaction}

Performance is a function of motivation, skills and perceptions of the role (Stoner, 1989). Additionally, Bernardin \& Russel (1993) stated that the performance is the recording of the results obtained from job functions or activities for a certain period. Islamic religious Performance always involves science and technology so that the qualities of religious work not the same as a regular performance. Humans are commanded to be able to master science and technology in order to become a man of Achievement and useful for the benefit of all mankind on earth.

Table $\mathbf{8}$ Sobel test $\left(\mathbf{H}_{\mathbf{1 0}}\right)$

\begin{tabular}{|c|c|c|c|c|}
\hline Input: & & Test statistic: & Std. Error: & $p$-value: \\
\hline a -0.195 & Sobel test: & 1.65954643 & 0.03701313 & 0.09700573 \\
\hline$b-0.315$ & Aroian test: & 1.60429856 & 0.03828776 & 0.10864826 \\
\hline$s_{a} 0.101$ & Goodman test: & 1.72092568 & 0.035693 & 0.08526431 \\
\hline$s_{\mathrm{b}} 0.097$ & Reset all & \multicolumn{3}{|c|}{ Calculate } \\
\hline
\end{tabular}

Computing Sobel Test of Mediation for Baron \& Kenny Approach, it can be shown that the value of the path coefficient Islamic leadership influence through job satisfaction on performance teacher at 1.659 and $p$ value of 0.097 . So that based on these results can be explained that the influence of Islamic leadership through job satisfaction on performance teachers is positive but not significant. On several occasions the principal as the direct supervisor of the teachers carry out their duties selflessly and always do the coaching, sharing knowledge with teachers without expecting anything in return and always prioritize the deliberation in the work plan, curriculum and lesson plans and the different interests and talents contained within teacher profession as a teacher, a feeling of discomfort in the work, and lack of satisfaction within themselves the educators and poor leadership improvement efforts undertaken for the welfare of teachers in the implementation proved unable to improve the integrity of teachers as educators.

\section{Conclusion}

Gained sufficient support teachers in harmonious relationships among teachers. The process of drafting the curriculum and Learning Implementation Plan (RPP), which is one teacher workload can be implemented optimally. Working conditions that support teachers to implement the learning process well is the cause of a positive and significant effect of work motivation on job satisfaction of teachers.

Teachers in carrying out their duties always act in an objective and non-discriminatory, teachers show empathy in communicating to fellow educators, parents and the community and teachers have a good attitude making it easier for them to adapt to the environment of diverse cultural and social backgrounds are different and the teacher continues to build communication with other professions and other professions both oral and written, so the impact on the high sense of satisfaction that is felt by teachers today to build a harmonious relationship with the boss and good relationships with colleagues throughout the profession as well as the positive response from the employer to the achievement obtained by teachers during this so that the deciding factor in the creation of teacher job satisfaction work. School principals have the ability to always on the straight and always use the same size in the act are realized with equal treatment for teachers and the community around the school and make an assessment of the achievements of teachers to justice without looking at the background of teachers, in its implementation proved able to increase the interest of teachers, tranquility work, attitude towards work and the welfare of teachers, which later became the cause positive but not significant influence of Islamic leadership on job satisfaction of teachers.

The high desire of teachers to obtain awards for his work so far and praise for the work that is inversely proportional to the low level of ability of teachers to the mastery of instructional materials and is represented on the ability of teachers of the method or process of preparing program of learning activities to develop syllabi and lesson plan (RPP) which later became the cause of a negative and significant effect on the performance of teachers' work motivation.. 
The teachers ability to communicate and interact effectively with the school environment and outside the school environment so as to improve the ability of teachers to conduct an evaluation of what has been achieved and done but the real effect is not sustained, the condition causes no significant positive effect on the performance of teachers' competence. Teachers do the job always act in an objective and non-discriminatory and continually communicate empathetically to fellow educators, parents and the community and able to adapt to diverse environments and cultures of different social background.

The principal as the direct supervisor of teachers have the ability to always be on the straight path and the actions and policies pursued by constantly using the same size in the face of the problems faced by teachers that have a significant impact on the ability of teachers to conduct an evaluation of what has been achieved that be sustainable. The low level teachers have conformity with the interests and talents contained within them, a feeling of discomfort in the work, and lack of satisfaction within themselves the educators, proven to provide a significant impact on the high commitment of teachers in improving the quality of learning implementation.

Low desire of teachers to further pursue personal achievement of the material benefits are realized with passion educating always better than the results previously achieved, but inversely with lower job satisfaction felt by a teacher who is shown with a lower inability of teachers in working time arrangements and the lack of facility supplies teachers' work and also lower the ability of teachers to be honest and have strong character in attitude and action, but it resulted in a decrease in the ability of teachers to provide a description of the knowledge, skills and attitudes to students

causative factor of negative and significant effect of competence through job satisfaction on performance teachers due to teacher in carrying out its work always act in an objective and non-discriminatory and continually communicate empathetically to fellow educators, parents and the community and able to adapt to the environment of diverse cultural and social background is different, then the teacher has the ability to establish good communication significant impact on the high commitment of teachers in improving the quality of implementation of learning and ability of teachers to always strive to convey to students the teaching materials in accordance with the specified time target to trigger a negative and significant effect of competence through job satisfaction on the performance of teachers.

On several occasions the principal as the direct supervisor of the teachers carry out their duties selflessly and always do the coaching, sharing knowledge with teachers without expecting anything in return and always prioritize the deliberation in the work plan, curriculum and lesson plans and the different interests and talents contained within teacher profession as a teacher, a feeling of discomfort in the work, and lack of satisfaction within themselves the educators and poor leadership improvement efforts undertaken for the welfare of teachers in the implementation proved unable to improve the integrity of teachers as educators.

\section{References}

[1] Ahmad, K. (2009). Leadership and work motivation from the cross-cultural perspective. International Journal of Commerce and Management, 19 (1), 72-84.

[2] Ahmed, I., Nawaz, MM Iqbal, N., Ali, I., Shaukat, Z., \& Usman, A. (2010). Effects of motivational factors on employees job satisfaction a case study of the University of the Punjab, Pakistan. International Journal of Business and Management, 5 (3), 70.

[3] As'ad, Mohamad. (2004). Industrial psychology. Liberty: Yogyakarta

[4] Bakhri, S., modding, B., Gani, A., \& Lamo, M. (2015). Linking leadership style, work environment, job characteristics to Civil Servants performance: the mediating role of job satisfaction. International Journal of Humanities and Social Science Invention.7584

[5] Baron \& Greenberg.1990.Behaviorin organisasi, 3rd ed. Boston, MA: Allyn \& Bacon (A Division of Simon \& Schuster, Inc.)

[6] Baron, A., (2011). Measuring human capital. Strategic HR. Rev., 10: 30-35.

[7] Baron, R. M., \& Kenny, D. A. (1986). The moderator-mediator variable distinction in social psychological research: Conceptual, strategic, and statistical considerations. Journal of personality and social psychology, 51(6), 1173.

[8] Bernardin, H. John and Joyce EA Russell, 2000, Human Resource Management, Interpreting Diana Hertati, Mc. Graw Hill, Inc. Singapore

[9] Bernardin, H.John, and Joyce EARussel. (1993). Human Resource Management: An Approach Experential. Singapore: Mc. Graw Hill, Inc.

[10] Brahmasari, IA, \& Suprayetno, A. (2009). Influence of Work Motivation, Leadership and Organizational Culture on Employee Satisfaction and Impact on Corporate Performance (Case Study at PT. Pei Hai International wiratama Indonesia). Journal of Management and Entrepreneurship, 10 (2), 124.

[11] Cranny, CJ, Smith, PC, \& Stone, EF (Eds.). (1992). Job satisfaction: How people feel about Reviews their jobs and how it Affects Reviews their performance. Lexington Books.

[12] Danang Mukti Wibowo, (2014), Effects of competence, motivation, organizational commitment to employee performance and job satisfaction of education. International Juotnal of Business and Management. Vol.5, 6; June 2014

[13] Dhermawan, AANB, \& Good, N. (2012). Effect of Motivation, Work Environment, Competencies, and Job Satisfaction Compensation and Employee Performance in the Environment Office of the Public Works Department of Bali Province. Journal of Management, Business Strategy and Entrepreneurship, 6 (2), 173-184.

[14] Dwivedula, R., Bredillet, C., \& Müller, R. (2015). Towards an understanding of work motivation in temporary organisasi. PM World Journal, IV (IX), 1-12.

[15] Guay, F., Chanal, J., Ratelle, CF, Marsh, HW, Larose, S., \& Boivin, M. (2010). Intrinsic, identified, and controlled types of motivation for school subjects in young elementary school children. British Journal of Educational Psychology, 80 (4), $711-735$.

[16] Hair, J. F., Ringle, C. M., \& Sarstedt, M. (2013). Partial least squares structural equation modeling: Rigorous applications, better results and higher acceptance. 
[17] Halstead, JM (2007). Islamic values: a distinctive framework for moral education ?. Journal of Moral Education, 36 (3), 283 -296.

[18] Hardjanto, D. (2017). The Influence Of Compensation, Leadership, Competence To Employee Performance of RRI Surakarta With Motivation And Job Satisfaction As Intervening Variable. eAbstract Excellent, 3 (1).

[19] Kreitner, Robert. \& Angelo Kinicki. (2005). Organizational Behavior 2 (Issue 5). Salemba Four, Jakarta

[20] Kock, N. (2011). Using WarpPLS in e-collaboration studies: An overview of five main analysis steps. Advancing Collaborative Knowledge Environments: New Trends in E-Collaboration: New Trends in E-Collaboration, 180.

[21] Luthans, Fred (2006). Organizational Behavior, Tenth Edition, Publisher Andy, Yogyakarta

[22] Luthans, Fred. (1998). Organization Behavior. International Edition, Sixth. Edition. Management, 8th edition. USA: John Wiley and Sons

[23] Mahmood, A. (2006). Psychology and Shia Muslims. In ET Dowd \& SR Nielson (Eds.), The psychologies in religion: Working with the religious client (pp. 237-252). New York, NY: Springer.

[24] Mangkunagara, Anwar King. (2005). Human Resources company. Juveniles. Rosdakarya: Bandung

[25] Moeheriono. (2013). Competency-Based Performance Measurement. Jakarta: PT. King Grafindo Persada

[26] Namasivayam, K. \& B. Denizci, (2006). Human capital in service organisasi: Identifying value drivers. J. Intellect. Capital, 7: 381393.

[27] Rimadias, S., Ferli, O., \& Hertingkir, F. (2017). The Role of Work Motivation and Job Satisfaction in Creating Employee Performance (Study on Permanent Lecturers of STIE Indonesia Banking School). Journal of Management Science and Economics, 9 (1), 24-47.

[28] Robbins, S. P (2006). Fundamentals of organizational behavior., New Jersey, United States. Pearson Prentice Hall. Upper Saddle River

[29] Ruky, A. (2006). Qualified Human Resources Changing Vision Becoming Reality. Second printing. Jakarta: PT. Gramedia Pustaka Utama.

[30] Sholihin, Mahfud \& Ratmono, Dwi. (2013). SEM-PLS Analysis with WrapPLS 3.0 For Nonlinear Relationships in Social and Business Research. Yogyakarta: Andi Publisher

[31] Singh, SP, \& Sharma, HK (2016). Impact of Work Motivation on the Job Satisfaction of Teachers in Professional Education. The International Journal of Research Publication's. Research Journal of social science and management. Volume: 06 (05) .90-96

[32] Slamet, Hamid Muhammad \& Cecep Rustana. (2000). School-Based Quality Improvement Management. Jakarta: Ministry of Education.

[33] Stoner, James AF \& R. Edward Freeman. (1989). Management. Fourth Edition. Englewood Cliffs: Prentice-Hall International, Inc.

[34] Thoha Miftah. (2006). Leadership in Management. PT. King Grafindo Persada: Jakarta

[35] Timpe, A Dale, (1993). Performance Series Human Resource Management. Jakarta, PT. Elex Media Komputindo, Gramedia

[36] Tone, K., Gani, MU, Nujum, S., \& Latif, B. (2015). The impact of the antecedent variables on lecturer'performance as mediated by work motivation. International Journal of Humanities and Social Science Invention. 4 (10) 54-62

[37] Twenge, JM, \& Campbell, SM (2012). Who are the Millennials? Empirical evidence for generational differences in work values, attitudes and personality. In ES Ng, ST Lyons, \& L. Schweitzer (Eds.), Managing the new workforce (pp. 1-19). Edward Elgar Publishing Limited

[38] Wibowo. (2010). Perfomance Management. - Third Edition, Jakarta : PT. Raja Grafindo 